National and Global Petroleum Assessment

\title{
Assessment of Undiscovered Conventional Oil and Gas Resources in the Wyoming Thrust Belt Province, Wyoming, Idaho, and Utah, 2017
}

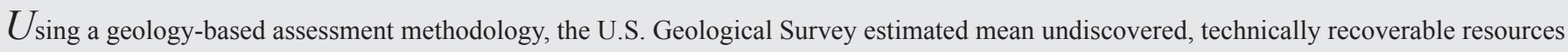
of 26 million barrels of oil and 700 billion cubic feet of gas in the Wyoming Thrust Belt Province, Wyoming, Idaho, and Utah.

\section{Introduction}

The U.S. Geological Survey (USGS) quantitatively assessed the potential for undiscovered, technically recoverable conventional oil and gas resources in the Wyoming Thrust Belt Province, which is located west of the Southwestern Wyoming Province, east of the Eastern Great Basin Province, south of the Idaho-Snake River Downwarp Province, and north of the Uinta-Piceance Basin Province (fig. 1). The Wyoming Thrust Belt developed by east-directed compression associated with steeply dipping subduction during the Late Jurassic to Late Cretaceous Sevier Orogeny (Lamerson, 1982; Webel, 1987). Compression resulted in a series of stacked thrust sheets that are progressively younger in age to the east. The major thrusts in the Wyoming Thrust Belt Province are the Paris-Willard, Meade, Crawford, Absaroka, Hogsback-Darby, and Prospect (fig. 1). Exploration in the mid-1970s resulted in the discovery of more than 30 oil and gas fields, most of which are associated with the Absaroka thrust sheet. Compared to the Absaroka, exploration along the other thrust sheets has been largely unsuccessful. The temporal sequence of thrust loading and structural deformation has resulted in a complex evolution of petroleum systems in the Wyoming Thrust Belt Province (Warner, 1982; Edman and Surdam, 1984; Burtner and Nigrini, 1994).

\section{Total Petroleum System and Assessment Unit}

The USGS defined the PaleozoicMesozoic Composite Total Petroleum System (TPS) and the Wyoming Thrust Belt Conventional Oil and Gas Assessment Unit (AU) within this TPS. The Paleozoic-Mesozoic Composite TPS includes petroleum generated from organic-rich shales of the Lower Permian Phosphoria Formation and the Lower Cretaceous Aspen Shale (equivalent to the Mowry Shale). Organic-rich shales of the Phosphoria Formation contain Type IIS marine organic matter (Lillis and Selby, 2013), have total organic carbon (TOC) contents averaging 4 weight percent even with high levels of thermal maturation (Burtner and Nigrini, 1994), and are as much as 50 meters (m) thick (Maughan, 1984). Aspen Shale contains Type II and Type I organic matter, has TOC contents up to 3 weight percent (Warner, 1982),

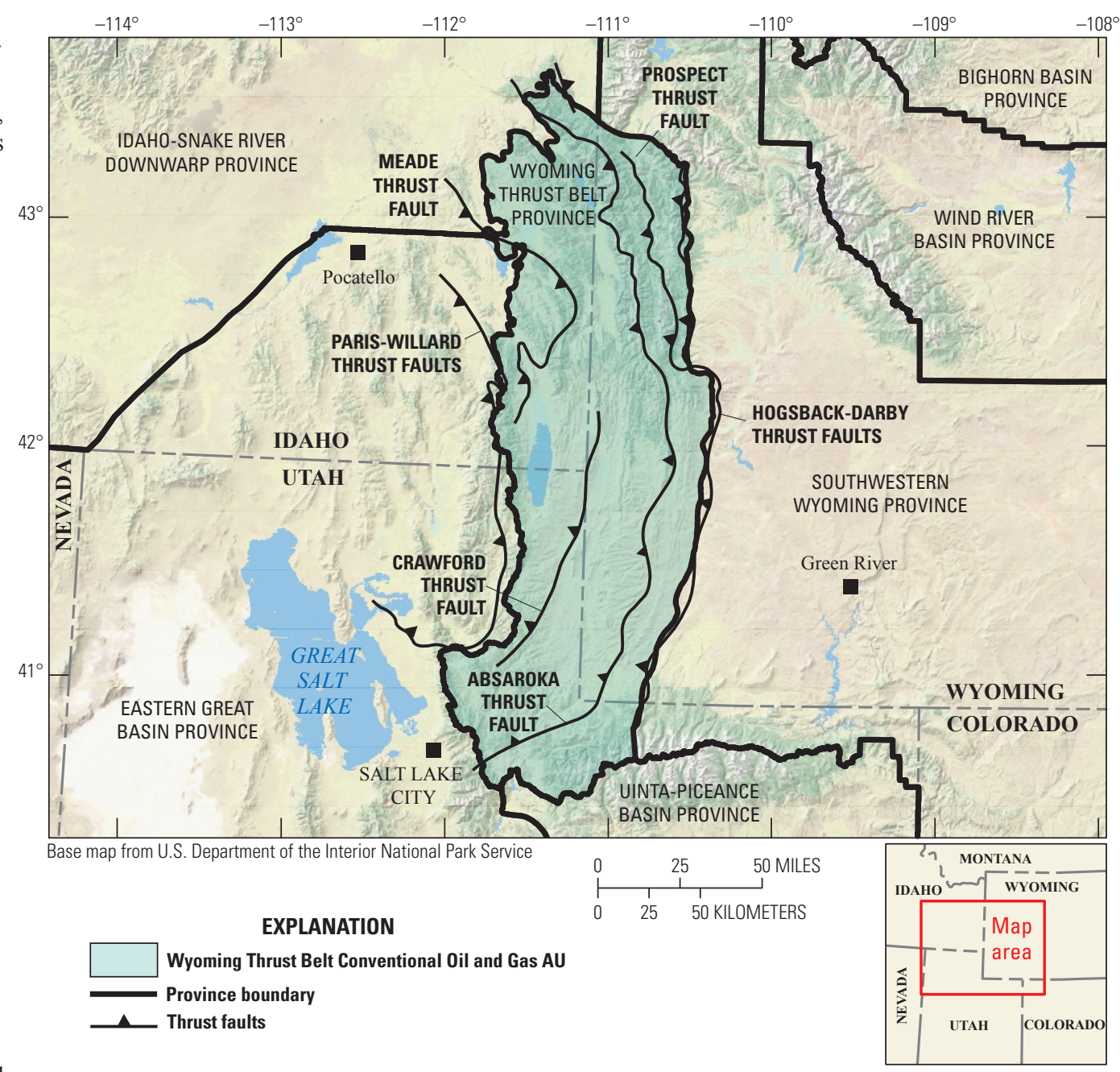

Figure 1. Map showing the location of one conventional assessment unit (AU) in the Wyoming Thrust Belt Province, Wyoming, Idaho, and Utah. and ranges up to $20 \mathrm{~m}$ thick. The Wyoming Thrust Belt Conventional Phosphoria Formation and oil and gas from the Aspen Shale.

The assessment input data are summarized in table 1.

\section{Geologic Model for Assessment}

The geologic model for undiscovered conventional oil and gas resources in the Wyoming Thrust Belt Conventional Oil and Gas AU includes gas and minor oil generated from the Phosphoria Formation and oil and gas from the Aspen Shale that migrated into conventional reservoirs within structural traps. Phosphoria Formation shales are interpreted to have reached thermal maturity for oil generation prior to the development of most thrust-related structures (Warner, 1982; Burtner 
and Nigrini, 1994), and much of the Phosphoria Formation oil migrated eastward into traps in what are now the Laramide basins in Wyoming, Montana, and Colorado (Lillis and Selby, 2013). Following oil migration, any oil retained within the Phosphoria Formation shales in the Wyoming Thrust Belt Province would have cracked to dry gas from thrust loading that occurred throughout Sevier and Laramide deformation. Most of the Phosphoria Formation shales in the thrust belt are now within the thermal window for dry gas or are postmature for gas (Edman and Surdam, 1984).

The Lower Cretaceous Aspen Shale reached thermal maturity for generation of oil and gas coincident with movement of the major thrust sheets during the Sevier Orogeny (Warner, 1982; Edman and Surdam, 1984; Burtner and others, 1994). These shales are the primary source for oil in the conventional reservoirs of the thrust belt, but gas has also been generated from the Aspen Shale (Warner, 1982).

Reservoir rocks are mainly carbonates within the Ordovician Bighorn Dolomite, the Mississippian Madison Group, Pennsylvanian Amsden Formation, Lower Permian Phosphoria Formation, Lower Triassic Thaynes Formation, Middle Jurassic Twin Creek Limestone, Pennsylvanian Weber and Tensleep Sandstones, and Jurassic Nugget Sandstone.

Table 1. Key assessment input data for one conventional assessment unit in the Wyoming Thrust Belt Province, Wyoming, Idaho, and Utah.

[AU, assessment unit; MMBO, million barrels of oil; BCFG, billion cubic feet of gas. Shading indicates not applicable]

\begin{tabular}{|l|c|c|c|c|}
\hline \multirow{2}{*}{ Assessment input data } & \multicolumn{4}{|c|}{ Wyoming Thrust Belt Conventional Oil and Gas AU } \\
\cline { 2 - 5 } & Minimum & Median & Maximum & Calculated mean \\
\hline Number of oil fields & 1 & 10 & 30 & 10.6 \\
\hline Number of gas fields & 1 & 40 & 120 & 42.5 \\
\hline Sizes of oil fields (MMBO) & 0.5 & 1.0 & 100 & 2.5 \\
\hline Sizes of gas fields (BCFG) & 3 & 6 & 600 & 14.9 \\
\hline AU probability & 1.0 & & & \\
\hline
\end{tabular}

\section{Undiscovered Resources Summary}

The USGS quantitatively assessed undiscovered conventional oil and gas resources within the Wyoming Thrust Belt Province (table 2). The estimated mean totals for undiscovered oil and gas resources are 26 million barrels of oil (MMBO) with an F95-F5 range from 7 to $66 \mathrm{MMBO}$, 700 billion cubic feet of gas (BCFG) with an F95-F5 range from 262 to $1,397 \mathrm{BCFG}$, and 45 million barrels of natural gas liquids (MMBNGL) with an F95-F5 range from 15 to 94 MMBNGL.

Table 2. Assessment results for one conventional assessment unit in the Wyoming Thrust Belt Province, Wyoming, Idaho, and Utah.

[MMBO, million barrels of oil; BCFG, billion cubic feet of gas; NGL, natural gas liquids; MMBNGL, million barrels of natural gas liquids. Results shown are fully risked estimates. For gas accumulations, all liquids are included in the NGL category. F95 represents a 95-percent chance of at least the amount tabulated; other fractiles are defined similarly. Fractiles are additive under the assumption of perfect positive correlation. Shading indicates not applicable]

\begin{tabular}{|c|c|c|c|c|c|c|c|c|c|c|c|c|c|c|}
\hline \multirow{3}{*}{ Total petroleum system and assessment unit (AU) } & \multirow{3}{*}{$\begin{array}{c}\text { AU } \\
\text { probability }\end{array}$} & \multirow{3}{*}{$\begin{array}{c}\text { Accumulation } \\
\text { type }\end{array}$} & \multicolumn{12}{|c|}{ Total undiscovered resources } \\
\hline & & & \multicolumn{4}{|c|}{ Oil (MMBO) } & \multicolumn{4}{|c|}{ Gas (BCFG) } & \multicolumn{4}{|c|}{ NGL (MMBNGL) } \\
\hline & & & F95 & $\mathbf{F 5 0}$ & F5 & Mean & F95 & F50 & F5 & Mean & F95 & $\mathbf{F 5 0}$ & F5 & Mean \\
\hline \multicolumn{15}{|c|}{ Paleozoic-Mesozoic Composite Total Petroleum System } \\
\hline \multirow{2}{*}{$\begin{array}{l}\text { Wyoming Thrust Belt Conventional Oil and } \\
\text { Gas AU }\end{array}$} & \multirow{2}{*}{1.0} & Oil & 7 & 21 & 66 & 26 & 18 & 52 & 166 & 66 & 2 & 5 & 17 & 7 \\
\hline & & Gas & & & & & 244 & 574 & 1,231 & 634 & 13 & 34 & 77 & 38 \\
\hline Total undiscovered conventional resources & & & 7 & 21 & 66 & 26 & 262 & 626 & 1,397 & 700 & 15 & 39 & 94 & 45 \\
\hline
\end{tabular}

\section{References Cited}

Burtner, R.L.; and Nigrini, Andrew, 1994, Thermochronology of the Idaho-Wyoming Thrust Belt during the Sevier Orogeny-A new, calibrated, multiprocess thermal model: American Association of Petroleum Geologists Bulletin, v. 78, no. 10, p. 1586-1612.

Burtner, R.L.; Nigrini, Andrew; and Donelick, R.A., 1994, Thermochronology of Lower Cretaceous source rocks in the Idaho-Wyoming Thrust Belt: American Association of Petroleum Geologists Bulletin, v. 78 , no. 10 , p. $1613-1636$.

Edman, J.D., and Surdam, R.C., 1984, Influence of overthrusting on maturation of hydrocarbons in Phosphoria Formation, WyomingIdaho-Utah Overthrust Belt: American Association of Petroleum Geologists Bulletin, v. 68, no. 11, p. 1803-1817.

Lamerson, P.R., 1982, The Fossil Basin and its relationship to the Absaroka thrust system, Wyoming and Utah, in Powers, R.B., ed., Geologic studies of the Cordilleran Thrust Belt, volume I: Denver, Colo., Rocky Mountain Association of Geologists, p. 279-340.
Lillis, P.G.; and Selby, David, 2013, Evaluation of the rhenium-osmium geochronometer in the Phosphoria petroleum system, Bighorn Basin of Wyoming and Montana, USA: Geochimica et Cosmochimica Acta, v. 118, p. 312-330.

Maughan, E.K., 1984, Geologic setting and some geochemistry of petroleum source rocks in the Permian Phosphoria Formation, in Woodward, Jane; Meissner, F.F., and Clayton, J.L., eds., Hydrocarbon source rocks of the Greater Rocky Mountain region: Denver, Colo., Rocky Mountain Association of Geologists, p. 281-294.

Warner, M.A., 1982, Source and time of generation of hydrocarbons in the Fossil Basin, western Wyoming Thrust Belt, in Powers, R.B., ed., Geologic studies of the Cordilleran Thrust Belt, volume II: Denver, Colo., Rocky Mountain Association of Geologists, p. 805-815.

Webel, Suzanne, 1987, Significance of backthrusting in the Rocky Mountain Thrust Belt, in Miller, W.R., ed., The thrust belt revisited: Jackson Hole, Wyoming Geological Association, 38th Annual Field Conference, Guidebook, p. 37-53.

\section{Wyoming Thrust Belt Province Assessment Team}

Christopher J. Schenk, Tracey J. Mercier, Marilyn E. Tennyson, Cheryl A. Woodall, Michael E. Brownfield, Phuong A. Le, Timothy R. Klett, Stephanie B. Gaswirth, Thomas M. Finn, Kristen R. Marra, and Heidi M. Leathers-Miller

\section{For More Information}

Assessment results are also available at the USGS Energy Resources Program website at https://energy.usgs.gov. 